\title{
Cultivating And Promoting A Culture Of Reading Among Fathers Of Men
}

\author{
Dr. Jagtar Singh \\ Reader and Head \\ Punjabi University \\ Department of Library and Information Science \\ Patiala - 147 002, INDIA
}

\begin{abstract}
William Wordsworth has rightly said that the child is father of the man. The whole story of human progress is based on the creative spirit of mankind. Hence it is essential for us to empower the child with critical thinking, decision making, and problem solving skills from his childhood. School libraries and public libraries have a pivotal role to play in this regard, but that is possible only when these libraries themselves are properly developed. School libraries are the weakest link in library and information infrastructure in India. This paper highlights the factors responsible for a declining culture of reading among children in India and also suggests the ways to promote the reading culture from the early days of childhood.
\end{abstract}

I would like to begin this paper by referring to its moorings, which lie in the following lines from the famous English poet William Wordsworth:

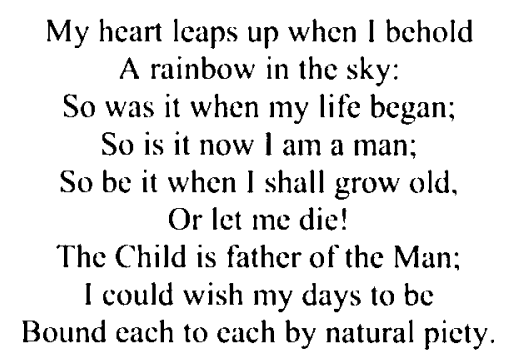

\section{Power of the book}

It is a well-known fact that a good book is a hot medium, but TV is a cool medium. A good book fires imagination of the reader whereas the viewer is carried away with TV programmes and does not find time to reflect on what he is viewing. It has been reported in a doctoral study (Avtar Singh, 1995, p.251) that TV viewing also has a negative impact on children as they become careless, aggressive, absentminded, and backward in studies, irritable, un-disciplined, selfish, boastful, teasing, and disobedient. To counter this, it is therefore necessary to develop among children the culture of reading good books. There may be some substance in Marshal McLuhan's 'medium is the message' and Nicolas Negroponte's 'message is the medium' perceptions, but there can be no two opinions about the effectiveness of a good book in empowering the reader. Knowledge is power, but information is instant power. A good book, therefore, is a source of instant power as it facilitates interaction between reader's imagination and author's experience and thus helps a human being to become a human resource. Education, information, and entertainment are essential for personality development of a child, because "knowledge will forever govern ignorance; and people who mean to be their own governors must arm themselves with the 
power which knowledge gives." (Madison, 1822). Public and school libraries are vital links in the whole proeess of being and developing as a child. UNESC $O$ and IFLA believe that,

\author{
the school library provides information and ideas that are findamental to \\ finctioning successfilly in todar's information and knowledge-hased society. \\ The school library equips students with life-tong learning skills and develops \\ the imagination, enabling them to live as responsible citizens (UNESCO/IFLA \\ School Library Manifesto).
}

Libraries have a pivotal role to play in preserving the past, serving the present, and creating the future by developing good collections of books and serving the same to the stakeholders with the help of leading-edge technologies. Although every library has its own community to look after, all types of libraries are required to develop the capacities of the human resource and this effort must begin from childhood. In this context, school and public libraries must be developed as strong links in the library and information infrastructure of a nation, as the strength of a chain is undermined by its weakest link.

Unfortunately, school and public libraries are the weakest link in library and information infrastructure in India. Only public schools have good library collections. In government schools, the condition of libraries is pitiable wherever they exist. In many cases, school librarians are required to teach classes, and in other cases teachers are given charge of these libraries. Textbooks are generally available, but there is a lack of literature for general reading in these libraries, particularly in local languages. This greatly hampers the development of the libraries and culture of reading among children. In addition, the syllabi for different grades are very heavy and leave little time for children to use school libraries for leisure reading.

Parents, teachers, governments, libraries, book trade, and authors of children books all have a critical role in promoting the culture of reading among children. In India, efforts have been made to develop a book culture by establishing national bodies, such as Sahitya Academy, National Book Trust (NBT), National Council for Education, Research and Training (NCERT), and Raja Rammohun Roy Library Foundation (RRRLF), and boards of language. literature, and culture at state level. School libraries must develop into hybrid libraries with balanced collections of printed books and electronic resources. Video games, story hours, competitions, library weeks, and book fairs and exhibitions can go a long way to promote the culture of reading among children. However, the syllabi must be reduced and fine-tuned to develop critical thinking, decision making, and problem solving abilities among the young readers. Irrelevant historical details in the syllabi should be eliminated to reduce load on child's memory. Textbooks dealing with the language, literature, and culture of diverse communities in India should represent a true manifestation of the composite culture of the country. There should be no compromise on the quality, cultural diversity, and equity reflected. Only in this way would lingual minorities in India embrace the culture of reading. Lack of language aceess to cultural heritage of diverse communities in India is the biggest hurdle to the culture of reading.

The real language, literature, and culture of Indian diasporas is under great threat as the new generation is rapidly moving away from its cultural moorings under coeval influences in the name of modernity. There is no harm in adopting good things from other cultures, but that should not be at the cost the cultural moorings of the concerned communities. Children become easy victims of these influences. Therefore there is a very strong need to promote the culture of reading good books among children from their earlier 
years. However, the Indian mind-set is heavily dependent upon the oral tradition. The emotional, spiritual, and cognitive reading needs of majority of parents in India are fulfilled by the discourses available to them in real life and virtual situations (CTV). Very few parents revert to reading after listening to such discourses and there is no culture of reading among parents at home; it certainly affects the minds of children negatively in this regard. At school, the library is not considered to be a critical link to support the teaching and learning process. Moreover there is no flexibility in the syllabi to allow creative use of the library. In India, there is no national policy on library and information system. Further, there is no reference to the role of libraries in teaching and learning in the New Education Policy document of India. Low levels of literacy and the ascent of CTV are key factors responsible for the declining reading culture in India.

The case studies of a school library and a mobile library project are discussed in this context.

\section{Budha Dal Public School}

Budha Dal Public School (BDPS), a co-educational English medium, secular institution affiliated to the Central Board of Secondary Institution (CBSE), New Delhi was formally opened on 6 May 1984 by the Sikh Educational Society, Shromani Budha Dal. Panjwan Takhat (Regd), Patiala. At that time it had only Nursery Wing with 15 students, three teachers, and four rooms. Today, it has Humanities, Commerce, Medical, and NonMedical streams with 3000 students, 150 teachers, and 150 rooms, besides libraries and computer laboratories in its respective wings. The Patiala Campus is organised into three wings, i.e. the Nursery Wing (Nursery, Prep-I \& Prep-II Classes), Junior Wing (I-IV Classes), and Senior Wing (V-XXII Classes). At present, it is one of the best public schools in Punjab State of India. The school is making concerted efforts to impart understanding of the value of education with school motto to serve, strive and conquer. Integrity, wisdom, love, truth, faith, freedom, aesthetics, and equity are core values being inculcated by the school. The vision of the school is not only to develop learned individuals, but also better human beings. Its strategic focus is to give education a new meaning, not by just amassing knowledge, but by creating knowledge through an active learning process informed by critical inquiry. Besides catering to the educational needs of the urban students, the Sikh Educational Society has a very strong commitment to the preservation of Sikh heritage and spread of education among the rural masses. With this commitment in mind, it has also opened a Secondary School in the Samana town of Patiala revenue district of Punjab State. (India has 26 States, six Union Territories, and a National Capital Territory.) In the Samana town of Punjab, there is no other recognised Public School to cater to the educational needs of the rural people. In the near future, the Society has plans to open three new schools with focus on Sikh heritage, vocational education, and empowerment of the rural 'have nots' respectively.

\section{International perspective}

The school is very keen to enter into international partnerships. In case of vocational education, the management of the school has made visits to different countries of the world. The school students and teachers have visited a few foreign countries on educational and cocurricular assignments. The school is also a member of the International Association of School Librarianship (IASL). It was the only school in India to be awarded 'UNESCO Book 
Project Award' for the year 1999, and the 'IASL/WINNEBAGO Progressive School Library Media Award' in 2000. Mr. Paramjit Singh alias Baba Uday Singh, Vice-President of the Budha Dal Public School, Patiala travelled all the way to Malmo in Sweden to receive this prestigious award on the auspicious occasion of the 2000 IASL Conference.

\section{The BDPS library and computer laboratory}

The BDPS Library is located in two big rooms and a long reading hall. It has a seating capacity for about 50 students at a time. Its opening hours are similar to the school timings, i.e. from 7-15 a.m. to $1-30 \mathrm{p} . \mathrm{m}$. in the summer, and $8-30$ to $2-00 \mathrm{p} . \mathrm{m}$. in the winter. It has more than 8000 books in English, Punjabi, and Hindi languages. Besides 1000 reference books, it has 3000 textbooks, 2000 fiction books, and 500 books each on science, commerce, and religion. It subscribes to 15 magazines on information technology, science, and education. It has also a CTV for the edu-tainment and info-tainment of the library users. Every class has one library period per week, and about 250 students visit the library daily to use its resources and services for their project and course-related work. Two books are issued to a student for one week but there is a provision for them to renew books. There is no limit on the number of books for home lending in case of teachers. There is no fixed budget for the library, but at the same time there is no restriction on acquiring the needed books. Teachers, students, and the library staff actively participate in the collection development for the library. The school has also a computer laboratory with 50 computers and a few of them have the Internet connectivity. Students are encouraged to make creative use of the lab to support their learning process.

\section{Mobile library service project}

Anant Education \& Rural Development Foundation (U.S.A.), a Non-resident Indian (NRI) organisation has started a mobile library service with one van for about 15 villages of Ludhiana district of Punjab, but the problem with this initiative is that the number of books is less than 500 and majority of these are either in English or Punjabi language while the readers are also interested in Hindi and Urdu language books. Moreover the number of books for children in local languages is very limited. On the top of this, the main driving force behind this project lives in U.S.A. and only occasionally visits India. Thus a driver and part time librarian manage the whole operation. In other words, the project is still in the process of formalisation. Moreover there are 17 districts, 138 blocks, and 12795 inhabited villages in Punjab, one mobile van full of books is not going to make much difference, but it can serve as a motivating factor for the Government of Punjab and other stakeholders for developing rural public library service.

The intention of the NRI Organization is good and the cause is noble, but the rural 'have-nots' have their problems and priorities. Poverty and illiteracy negatively affect the culture of reading among rural folk, not only in Punjab, but also across India. Punjab has a total population of 20.3 million, out of which 14.3 million are rural dwellers according to 1991 census. Out of the total population only $65.66 \%$ males and $50.41 \%$ females are literate, whereas the corresponding literacy rates for whole of India are $75.85 \%$ for males and $54.16 \%$ for females (2001 census). Kerala state of India has the highest literacy rate at $90.92 \%$ whereas Bihar state has the lowest $(47.53 \%)$. These statisties indicate that there is wide variation literacy throughout India. There may be many such mobile library initiatives in rural India, information about which is not easily available. 
This NRI Organisation is also actively co-operating with Punjab Library Association for enactment of public library law in Punjab. Punjab Public Library Act would be a big boost for development of comprehensive public library service in rural and urban Punjab.

\section{Strategies for promoting reading habits}

The mission of providing free primary education to all the children up to the age of 14 in India can not be realised without providing the necessary library facilities for children. Moreover, many children from poor families are not in a position to pursue higher education, and thus relapse into relative illiteracy after leaving school. In this case, strong public library systems are needed at grass root level to sustain literacy and promote the culture of reading. Raja Rammohun Roy Library Foundation. Kolkata, a nodal agency for developing and promoting public library systems and services in India, has a critical role to play in this regard. It must try to provide access to literature pertaining to the cultural diversity of India. The National Library of India and State Central Libraries also have a pivotal role to play in improving language access to India's documentary heritage. At national, state, and school level, school libraries must be considered as an integral part of policies and strategies for promoting the culture of reading and all round development of the personality of the child. There is no other way to support the goals of India's ambitious National Literacy Mission (1998) Total Literacy Campaign (TLC). The education system at school level also needs overhauling to provide more time for extra reading besides compulsory reading. Friends, parents, teachers, and librarians must work proactively to promote the culture of reading among children. In order to promote reading, good books should be gifted to children at social occasions. This will help children to know their past and build their future because a good book and a good library are supposed to preserve the past, serve the present, and create the future. Good books and reading will help the child in materialising his mission and develop his competence to face the life time challenges.

\section{Conclusion}

We must catch the child young because the mind the child is just like a sheet of plain paper. Books can provide good company to children and support learning, information and recreation. Video games and multimedia simulations are good for engaging the child, but are no substitute for good books that help all round development of personality. Reading is essential in the very beginning as the child is to become father of the man in future. The future of mankind is dependent upon the positive growth and development of child. Moreover, in the emerging knowledge economy only competent people will survive and thrive. Good books are permanent sources of knowledge and wisdom of mankind. Therefore, the culture of reading must be promoted as viewing can not replace reading. In India, production of children's literature in vernacular languages is a pre-condition for promoting the culture of reading along with elimination of illiteracy and poverty, particularly in rural areas.

\section{References and further reading}

Singh, A. (1995). Impact of Television Programmes on the Socio-Psychological Behaviour of Urban Primary School Children as Perceived by their Parents. (Unpublished Ph.D. thesis, Faculty of Education, Punjabi University, Patiala, Punjab-India). 
Doiron. R. (2003). Motivating the Lifelong Reading Habit through a Balanced Use of Children's Information Books. School Lihraries Worldwide, $9(1)$. Abstract accessed at: http: www iasl-slo.org/slw.html

Huffaker. D. (2004). Spinning yarns around digital fire: storytelling and dialogue among youth on the Internet.

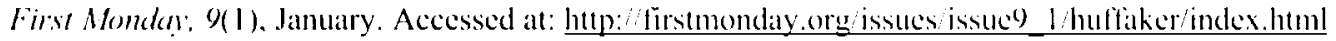

Ministry of Information and Broadeasting. (2004). India 20(1)4: a referenc'e' Ammal. New Delhi: Publication Division. Ministry of Information and Broadcasting, pp. 7-15.

Singh. J. (2003). Information Democracy and South Asia: Promises and Perils of the Heb. Ludhiana: Medallion Press.

Loertscher, D. (2002). Building knowledge rich environments for youth: a worldwide challenge for schools and school librarians. Keynote address at the 2002 IASL Conference, Petaling Jaya, Malayasia.. Access at: bup: Www iasl-slo.orgiconference2002-loetscher.html.

Madison. James (1822). Letter to W.T. Berry dated 4 August.

Rajaram. S. (1999). Strategies for promoting reading habits in India. Libraly Herald, 36(4). 251-257.

Tikekar. A.C. (2002). The book culture in India: with special reference to the Press \& Registration and the Delivery of Books Acts. (LIS Observer; 19(1-2), 59-63.

UNESCO/IFLA School Library Manifesto. Available at hıp:/Www.ifla.org.

\section{Author Note}

Dr. Jagtar Singh is Reader and Head, Department of Library and Information Science, Punjabi University, Patiala (India). He has 23 years of teaching and research experience and about 100 publications to his credit. His book, 'Information Democracy and South Asia: Promises and Perils of the Web' (2003) has been widely acclaimed in the professional circles. He is General Secretary of Punjab Library Association, and Vice- President of Indian Library Association. He is on the editorial board of ILA Bulletin, Information Research: An Electronic Journal, and South Asian Libraries and Information Networks (SALIN). His areas of interest are 'Information Management', 'Knowledge Management', 'Electronic Publishing', 'Resource Sharing', and 'Preservation and Conservation'. 